\title{
"What You Don't Know Can't Hurt You": The Right to Know and the Shetland Island Oil Spill
}

\author{
Gregory V. Button ${ }^{1}$
}

This paper, an account of the Shetland Islands oil spill (1993), examines the public health controversies surrounding the spill and the clean-up response. It critically examines the risk management policies of both the United Kingdom and the Shetland Islands Public Health Office, and suggests that the withholding of critical information contributed to increased anxiety and suspicion among the disaster victims. In an attempt to reassure the victims, the policies contributed to an increased air of uncertainty. It is further argued that the withholding of information prevents those who are at greatest risk from participating in critical decisions that may affect their health and livelihoods and asserts that a right-to-know policy is a critical first step in risk management practices.

KEY WORDS: Shetland Islands; oil spill; risk management; right-to-know; technological disasters.

\section{INTRODUCTION}

Chronic technological disasters are axial events because, as Eric Wolf (1990) has argued, "the arrangements of society become most visible when they are challenged by crisis." The study of these disasters is a quintessential example of the "anthropology of trouble" (Rappaport, 1993). In the aftermath of such disasters, people struggle to make sense of the event by interpreting it and assigning meaning and significance to the disaster. Disaster victims ask such questions as "Why me?" "Who is responsible?" "Who is to blame?" The turmoil that is engendered often creates radical shifts

${ }^{1}$ Department of Health Behavior and Health Education, School of Public Health and Department of Anthropology, University of Michigan, Ann Arbor, Michigan 48109. 
in people's world view. Often the frustrating failure to prevent such disasters and to respond satisfactorily to them brings into question social arrangements. In an atmosphere of uncertainty and a sense of the loss of control, there emerges a context over the way things are understood. The very process of meaning-making results in a bargaining about the meaning of reality (Comaroff \& Roberts, 1981; Rosen, 1984). In the conflict that is born of this process of meaning-making, people's ability to persuade others of their interpretation of reality, their perception of the problem, hinges on their power to do so (Edelman, 1977; Gusfield, 1981; Merry, 1990). In our own discourse about disasters it is paramount that we keep in mind what they can reveal about the social arrangements of society.

\section{RISK MANAGEMENT AND THE RIGHT-TO-KNOW}

Some of the most troubling questions raised in the wake of a technological disaster concern what public health officials know about the potential deleterious effects of the disaster and when (and if) they relay what they know to the general public (Levine, 1982; Jasanoff, 1988; Clarke, 1989; Reich, 1991; Button, 1993). A comparative analysis of technological disasters during the last two decades reveals that whether the disaster is located in Chernobyl, Love Canal, Bhopal, or Seveso, departments of public health have become departments of "reassurance," rather than candid bureaucracies that allow an informed public to make decisions about the well-being of their community. ${ }^{2}$ This approach may well be modeled, as Anthony Wallace (1987) has so astutely observed, on the contemporary approach to "risk management" which is predicated on the notion of a pressured bureaucrat who views public anxiety as a major administrative problem rather than being based on the perspective of the public which tends to view the real threat to public safety. Risk management strategies can run the risk of being too concerned with managing people's responses and diminishing the air of uncertainty, rather than with the actual management of risks.

Like the stochastic systems of risk analysis with their striving for "objective assessment" and their negation of the individual experience and the nonquantitative aspects of risk, risk management practices can exclude the perception and voice of the people exposed to risk. While risk analysts usually limit their definitions of risk to probability and magnitude, lay people in making risk assessments take into account qualitative factors such as equity, fairness, and controllability (Slovic, 1987).

${ }^{2}$ See Ozonoff \& Boden's (1987) superb analysis of public health agencies. 
The traditional problem-solving, institutionalized approaches of risk management do not serve the interests of local people nor can they perceive or articulate the concerns of local people because their very "objectivity" separates scientists from what is happening on the ground. Within such an approach there is little or no place for the native's perception and evaluation of risk (Rappaport, 1988). The failure to include this perspective alone suggests that anthropology - which values the native point of view - can make a significant contribution to both risk management/risk analysis and disaster research in general. ${ }^{3}$

An important component of risk analysis and risk management is public access to information. In democratic countries, the notion of a "right-to-know" resonates with cultural values to valorize the individual and his or her right to make informed decisions about health matters. However, governments and their agencies often construe differently from their citizens what their responsibility is for insuring access to information. Even in democratic nations which stress participatory decision-making public health officials have been reluctant to communicate in a forthright manner (Jasanoff, 1988).

To a large degree, government bureaucrats have taken their cue from the private sector. In many cases, the corporations involved in the controversies following a technological disaster adopt a public relations strategy that attempts to create a sense of certainty amid the atmosphere of uncertainty (Marrett, 1981). It is my contention that too many public health agencies are adopting a similar strategy. Public health policies formulated in response to technological disasters limit public discourse about scientific information and unwittingly, and perhaps at times, wittingly serve hegemonic interests beyond the public health domain. The fairness of the debate about the interpretation of a technological disaster in terms of assigning blame and responsibility, and what remedial and compensatory approaches should be taken, hinges on the availability of critical information. The Shetland Island oil spill serves as a classic example of the controversies surrounding such a debate and underscores the need to conceptualize hazardous environmental risk issues in context of human rights: namely the right-to-know. This assertion is predicated on the dictum offered by Shrader-Frechette (1991): "that there ought to be no imposition of risk, without the free informed consent of those who must bear it." The following ethnographic case study is based on original fieldwork that I conducted in the Shetland Islands shortly after the spill occurred.

${ }^{3}$ Along with Lave (1986), Latin (1988), and Freudenberg (1988), I view both risk analysis and risk management as one integrative process. 


\section{THE SHETLAND ISLAND OIL SPILL}

On January 5th, 1993, the American-owned oil tanker Braer went aground at Garth's Ness on the southern tip of the Shetland Islands. Amid a hurricane, the tanker was smashed into several sections and spilled 84,413 tons of Norwegian crude oil into the North Sea. This spillage was approximately twice the amount of the oil spilled in Alaska, by official estimate, following the wreck of the Exxon-Valdez. Coincidentally, this oil tanker wreck, the largest since the catastrophe in Alaska, also occurred at 60 degrees north latitude.

The Shetlands are an island archipelago located approximately 250 miles due west of Bergen, Norway and over 250 miles north of Aberdeen, Scotland. As in Alaska, many of the 22,500 inhabitants depend on maritime resources for their livelihoods. Until the 1970 s, economic livelihood on this remote region centered largely around fishing, wool, crofting, knitting, and subsistence farming. With the discovery of large quantities of oil 60 miles off Shetland's eastern shores, Sullom Voe, the largest oil port in Europe was constructed on the northern tip of the island (Rosen \& Vorhees-Rosen, 1978). ${ }^{4}$ While their are significant differences between the two spills, the Shetland Islands oil spill parallels the spill in Alaska in one other significant way. In Alaska, a minority ethnic group, Native Alaskans, were most adversely affected by the disaster and the clean-up that followed. In a similarly disturbing way, the "native" people of the Shetlands were also most adversely affected by the spill and the response effort. In both instances, the cultural way of life of both marginalized groups were threatened by the disasters and the emergency responses made by officials.

Sensing a story bigger than even the Exxon-Valdez spill, reporters from all over the world flocked to this remote northern island within hours. The press corps were not the only ones who had the Exxon-Valdez on their mind. Shetland Island officials and Scottish Office officials feared a tragedy of the magnitude of the Alaskan disaster, as well as criticism similar to the controversies surrounding the Exxon-Valdez clean-up effort. ${ }^{5}$ The ferocious winds blew not just oil vapors but oil droplets inland clear across the island

\footnotetext{
${ }^{4}$ In the 1960s, oil companies began to explore the North Sea for oil. In 1956, Britain and Norway formally agreed on how to divide the North Sea right down the middle. In 1969, Philips Petroleum discovered oil on the Norwegian side, and in late 1970, British Petroleum discovered oil on the British side (Yergin, 1992).

${ }^{5}$ In keeping with most European government practices, the United Kingdom assumed responsibility for the clean-up of the oil spill. This is in direct contradistinction to the United States' Government's decision to place Exxon in charge of the Exxon-Valdez oil spill. Although there are provisions under U.S. federal law to "federalize" a spill clean-up, the current practice in the United States is to hold the polluter responsible for the clean-up. For more information, see U.S. Congress Office Technology Report (1990).
} 
coating the houses and land of nearby communities with a brown gooey slime. Despite hurricane force gale winds and rough seas, officials decided to spray over 120 tons of chemical dispersants in 48 hours. ${ }^{6}$ While virtually ineffectual on the crude oil along the rocky coast, the dispersants contaminated the Shetland Islands' prime agricultural land and most of the nearby inhabitants, as well as several thousand sheep and cattle which had no shelter from either the storm or the chemical sprays. ${ }^{?}$

Four communities lie in close proximity to the island's airport and the tip of Garth's Ness. As United Kingdom airplanes took off from the runways they began spraying these toxic chemicals as soon as their wheels were up, in other words, at an altitude of 30 feet over the adjacent communities. ${ }^{8}$ The 3000 residents of Dunross Parish (located on the southern end of the islands) were not warned to stay indoors, were not informed of the times of the spraying, nor were they evacuated from the region. ${ }^{9} \mathrm{By}$ the time the spraying was terminated, almost all the inhabitants on the western side of the southern end of the island had been exposed to both the dispersants and the oil, including 18 pregnant women, most of whom were in the their first trimester of pregnancy.

\footnotetext{
${ }^{6}$ According to Malcolm Green, Executive Director of the Shetland Islands Council, and other sources, Green demanded that the U.K.'s Marine Pollution Control Unit (MPCU) assure him that the dispersants had been tested for safe use around humans. The MPCU gave Green assurances dispersants were safe. He later told me he was furious when he learned this statement was less than accurate. Ever since the sinking of the Torrey Canyon oil tanker off the coast of Great Britain in 1967, dispersants have had a bad name. The British dumped a phenomenal 10,000 tons of dispersants on 14,000 tons of crude oil. When the dispersants failed to work the Royal Navy Air Corps dive bombed the tanker attempting to set if afire. By then the oil had mixed with the water and their attempts failed. Dispersants are solvents that are used to breakdown the cohesiveness of the oil. They are sprayed on an oil spill in order to remove the oil from the surface of the water. The chemical agents cause the oil to enter the water column in tiny droplets. The oil droplets are then dispersed in the water column and become diluted ostensibly until they are in such low concentrations that they are considered harmless to the environment. Early dispersants were considered toxic, but current ones are considered somewhat less toxic (National Research Council, 1989). In rough seas and high winds, such as the conditions surrounding the wreck of the Braer, dispersants have been found to be ineffective.

${ }^{7}$ This was not the first time Shetland livestock were affected by an oil spill. On December 30, 1978, the Esso Britanica hit a concrete pier in the Sullom Voe port and spilled 1174 tons of oil. A flock of 2000 sheep grazing along the shore on an island across the sound were covered with oil. Fifty sheep were reported to have died from the oil (Wills, 1991, p. 87).

${ }^{8}$ Among my informants was a couple whose house was literally just several hundred feet from the edge of the end of the runway. The wife, who was pregnant, described being sprayed by the planes as she was approaching her cottage.

${ }^{9} \mathrm{Dr}$. Cox told me that they did not evacuate the 600 residents of the four communities because they did not want to create an air of uncertainty or arouse public fear. However, Dr. Hall told me that Cox initially was for evacuation until he spoke with Dr. Forbes of the Scottish Home Office. Pubic officials have often cited the fear of public panic for their reluctance to release all the information about disasters, however, research by Mileti et al. (1975), has demonstrated that in the face of a disaster most individuals do not become hysterical or irrational.
} 
The public health advisory issued by the Shetland Islands Council and by the local public health office simply advised residents to minimize skin contact with the oil and dispersants and stay indoors; advice that was difficult for the crofters who had to attend to their animals day and night during the storm and to the local school children who had to twice daily wait for school buses. Many of the other locals who had to go outside to commute to their jobs, and hundreds of airport employees were constantly exposed to the dispersants while at work. Only a small number of residents were provided with proper respiratory masks. For most, staying indoors did little good since even when they remained indoors they were nauseated by the odors that lingered in their homes for several days after the crisis passed. ${ }^{10}$

Moreover, during the first 10 days of the disaster there was no official clinical monitoring of the residents' health. The assessment of public health was impaired by the lack of necessary equipment for monitoring and measuring pollution levels. Most of the monitoring that was conducted was for gaseous hydrocarbon levels. There was no monitoring of oil droplets and no equipment for the monitoring of chemical dispersants in the atmosphere. The chemical content of the dispersants was unknown to both the people using them and those accidentally exposed to them. For the first 48 hours not even the Island's health official knew the chemical composition of the dispersants. The content of dispersants is generally a mixture of solvents and detergents many of which are toxic, however, their level of toxicity varies, and in some cases the toxicity of a dispersant is largely unknown.

Once Dr. Cox, the local public health official, was informed of the chemicals used in the spray he withheld the information from all other officials and the general public because of "commercial confidentiality." As Dr. Cox would later bemoan, his refusal to release this information and the chemical companies' insistence on withholding the information from the public $^{11}$ was the largest single factor for the pervasive feeling among the Shetlanders that there was a conspiracy to withhold vital information. ${ }^{12}$

\footnotetext{
${ }^{10}$ Dr. Gerald Forbes, the Director of the Environmental Health Unit at the Scottish Office made a public statement that there was no health risk from the odors. Forbes contended that the tests made inside the homes revealed there were no measurable hydrocarbons. The homes, however, were not tested for the presence of other harmful chemicals that were in the oil and dispersants.

${ }^{11}$ A British Petroleum employee told me that BP sent their employees (since BP operates the Sullum Voe oil terminal they employee a sizable number of people) a memo which told them that BP was going to "keep their heads down" and make no comment on the spill. Since there are so many BP employees in the Shetlands the rumor of this memo spread rapidly. A number of people told me that they interpreted this as yet another indication that a conspiracy was afoot. While BP had nothing whatsoever to do with the oil spill they were the manufacturers of one of the dispersants that were being used.
} 
Eventually, the high winds and rough seas split the tanker asunder and the oil appeared to wash out to sea, posing apparently little threat to the islands. But by the time the crisis had passed, all of the agricultural land and the adjacent salmon farms were condemned because of contamination from both the oil and the dispersants. Several million farm salmon had to be destroyed and a huge fish exclusion zone was established off the coast. While the international media corps went home disappointed that there wasn't a story as sensational as the Exxon-Valdez, an extended controversy began on the island that was all but ignored by everyone but the local press. With complaints of too few dead animals to photograph and severe weather that kept most indoors, the world press ignored the human story that unfolded (Button, 1994a).

\section{THE PUBLIC HEALTH CRISIS}

Almost immediately after the dispersants were sprayed, hundreds of Dunross Parish residents complained of eye and skin irritation, headaches, and diarrhea. Over 40 people experienced severe asthmatic responses. Later more than 250 people would demonstrate abnormal lung functioning. A smaller number would have test results that demonstrated renal and liver malfunction. Many of the local residents became alarmed. When Greenpeace and an environmental group from Norway disseminated literature that criticized the use of dispersants, residents grew uneasy. The also pointed out that dispersants have never been approved for use around humans and have unpredictable biological effects. The environmentalists cited reports that dispersants may adversely affect the amount of oil absorbed by the lungs and increase the rate of absorption of toxic oil in the mucous membranes of the mouth and nose. It was also revealed that one of the dispersants used on the spill (Dispolene 34s) was not licensed to be used in the U.K. Another one of the dispersants was criticized because it had never been approved for use along rocky shorelines. Yet another dispersant, it was learned, was banned in Norway because it failed toxicity tests.

\footnotetext{
${ }^{12}$ According to a number of informants, including officials of the Shetland Island Council there is considerable concern about secrecy and "conspiracies." For example, under Scottish law meetings are to be conducted in public; however, there is a process whereby public meetings including those of the council can be conducted as closed meetings if "commercially sensitive" matters are being discussed. It was under this veil of secrecy that the contract with BP to construct and operate the Sullom Voe facility was negotiated. Until this day, the general public does not know the conditions of the contract. According to Wills (1991), "very large subsidies from council funds are handed out in secret." These conditions contribute to the suspicion and cynicism of the public and no doubt contributed to their fears during the spill crisis.
} 
It wasn't until January 21 that U.K. Agriculture Minister David Curry admitted that one of the dispersants had failed tests to be used on rocky shorelines and that another dispersant hadn't even been tested for use along rocky coasts because it was not developed for such usage. Finally he stated: "The disclosure of this information underlines that residents of the south Mainland of Shetland were well justified in expressing misgivings about the use of dispersants."

The man who immediately found himself immersed in the middle of this controversy was Dr. Chris Rowlands, the general practitioner for the parish. In contrast to the assurances that all was well given by Dr. Cox, Dr. Rowlands advised school officials to not allow school children outside during recess. He also advised a public gathering that the crude oil contained three chemicals known to cause cancer: butadene, naphthlane, and benzene. He questioned the use of dispersants, telling another public group that U.K. officials were keeping the chemical contents of the dispersants a secret even from him, the parishioners' physician. Moreover, he alleged something that later was revealed to be true, that the U.K. was using an old, outdated stock of dispersants, and that they were unsure of their contents because they were mixing barrels of different chemicals. ${ }^{13}$

Alarmed over the symptoms many of his patients were exhibiting, Dr. Rowlands decided to begin clinical monitoring of his patients 2 days after the spill, at a time when the U.K. and local health board refused to conduct medical monitoring of the residents. Dr. Rowlands began taking blood and urine samples of the parishioners, especially those whose occupation forced them to spend most of their time outdoors. In an effort to conduct fuller tests, he phoned Dr. Campbell of the Scottish Health Board and asked him to begin tests on all the residents in the exposed regions. According to Rowlands, as eager as Dr. Campbell was to conduct the tests, he ran into severe opposition in the Scottish Home Office. However, once it was revealed in the press that Dr. Rowlands had been single-handedly conducting tests the Home Office relented. Unfortunately, this was at least 10 days after the spill, and because of the time delay the tests were almost meaningless; moreover, they failed to test for carcinogens like benzene, toluene, and zylene.

\footnotetext{
${ }^{13}$ Indeed the dispersants were so old that a number of the barrels stored at the Sumburgh Airport leaked and created their own spill problem. One of the security guards who worked at the airport informed me that some of the barrels were very old and rusty. A press release issued by the Shetland Island Council (1/27/93) stated that "It is not known how much has leaked but it could potentially be 500 gallons." The spill caused an uproar on the island and further damaged the reputation of the MPCU.
} 
Both Home Office officials and officials of the Shetland Islands Council pressured Dr. Rowlands to stop making public statements and conducting tests. Dr. Cox made public statements to the press that Dr. Rowlands was using scare mongering tactics and creating public hysteria. Cox also accused both Greenpeace and Bellona, a Norwegian environmental group, of being more of a public health hazard than the spill by causing unnecessary alarm. In an interview with me, Dr. Cox blamed the unrest on inflammatory statements made by "some individuals or groups from Alaska that told our people" that the public officials in Alaska withheld information and that U.K. officials would take the same tactic and must be challenged. ${ }^{14}$

Amid all this controversy, the islanders themselves were very concerned about the lack of testing and the use of dispersants. A petition, signed by several hundred people, to the Shetland Island Council demanded, among other things, that there be an open investigation of the disaster and that all information regarding the use of chemical dispersants be disclosed to the public. ${ }^{15}$ According to Martin Hall, Director of Environmental Health, even members of the Shetland Island Council were upset over the use of dispersants, but when they protested to the MPCU they were told, "I don't care if you like it or not we are going to do it." The controversy over the spraying of dispersants came to a head when residents in Scatness - a community immediately adjacent to the airport - and several airport employees threatened to sit down on the runways and block the planes from taking off. Malcolm Green, the Executive Director of the Shetland Island Council told me that it was at this point that he told the U.K.'s Department of Transport that he wanted the spraying discontinued. As a result of this demand a compromise was reached whereby spraying would be limited to certain areas and allowed only at certain altitudes (Shetland Islands Council Public Notice, 1/10/93).

\footnotetext{
${ }^{14}$ During the Exxon-Valdez oil spill, several grassroots community activists visited the Shetland Islands to investigate the unique arrangements the Shetland Island Council had negotiated with BP - the owner of the Sullum Voe oil terminal. Many of these individuals were in contact with the Shetland Islands once the spill there occurred and a small number flew from Alaska to the Shetlands in order to share the lessons learned from the Exxon-Valdez spill. All the Shetlanders that I encountered were very eager to hear first-hand about the spill in Alaska, including most Shetland Island Officials. Actually, the exchange between Alaska and the Shetlands predates this era considerably. In the 1970 s, Alaskan politicians came to the Shetlands to inspect the Sullum Voe terminal and the arrangements between the Shetland Island Council and BP. For an excellent history and account of the oil industry in the Shetlands see Wills (1991).

${ }^{15}$ Salmon fishermen and fish processors issued a joint statement as well opposing the indiscriminate use of dispersants.
} 
The official word from the Scottish Home Office from the first day of the spill was that there would be no long-term health effects from the spill or the use of dispersants. This claim was largely unsubstantiated. For one thing, this spill was unique in that it was the first known instance of respirable oil droplets, rather than vapor being blown ashore and there were no pre-existing studies of the possible health hazards of such an event. To make matters worse, chemical dispersants were being used in unauthorized areas and contaminating nearby settlements. Furthermore, although there are some studies that suggest that dispersants increase the dangers of oil inhalation, we have no scientific knowledge of what effect the combination of oil and dispersants has on the human body. The only givens were that both the oil and the chemicals contained known carcinogens. Under these circumstances, accepted scientific practice would require the assumption of a risk and the taking of preventative action and monitoring the environment and the human population.

In some ways, officials were monitoring animals better than people. Sheep and cattle that had died during the disaster were autopsied and biopsies were performed on the tissues of animals that were ill. However, as with the human medical situation, the test results were not released to the general public nor even to the veterinarian of Dunross Parish. The veterinarian was as unable as Dr. Rowlands to obtain information for his clients.

Not until 11 days after the wreck occurred did the Scottish Office begin a limited medical survey of the population. Out of 640 individuals invited to participate 460 were tested along with a control group of 96 individuals from the northern end of the island. The report showed no significant differences between the two populations. However, the tests were conducted far too late to detect the presence of toxic chemicals that may have been present in the body during the spill crisis and far too early to detect cellular abnormalities. Nor were tests conducted to monitor known carcinogens such as benzene (Fogg, 1993). In keeping with the secrecy surrounding the spill, Dr. Rowlands was not shown the test results until 2 hours before the press conference at which the results were announced. Given such little time to review the report Dr. Rowlands was effectively stopped from making a meaningful contribution to the press conference.

\section{CULTURAL CONSIDERATIONS}

The human world, as Rappaport (1988) reminds us, does not consist merely of chemical and biological processes alone, but is saturated with meaning and value. Historically there are cultural conditions that predate 
the North Sea oil era. For example, there are attitudes about off-islanders that figure predominately in the suspicion and distrust many islanders exhibited during the period of crisis. Native Shetlanders have a deep attachment to their non-British history and many identify strongly with their Scandinavian ancestry. Both the English and Scottish nationals who arrived en masse after the development of oil to work in the expanded economy were and are viewed with suspicion as "off-islanders": people who are insensitive to the Shetland way of life and who represent British "neo-colonialism."16

More importantly, the crofts and the crofters are viewed by island natives as symbolizing an ancient way of life. ${ }^{17}$ Crofts are viewed as land to which people have an inalienable right. They were originally protected in the larger context of Scottish Nationalism in the 1886 Act which made landlords powerless in making decisions that affect the use of crofting lands. While this special status was revoked in 1911, a new Crofters Act was produced in 1955 after a government report (The Taylor Report, 1954) argued for the protection of crofting communities because "they embody a free and independent way of life which in a civilization predominately urban and industrial in character is worth preserving for its own intrinsic quality" (Parman, 1990). While today crofting is not a viable economic project for most, it is nevertheless an important way of life (Cohen, 1987).

The crofts are also landmarks that resonate with great symbolic significance since a family may have resided in a particular croft for many generations. Crofters' cottages are commonly built on, or around, the remains of earlier dwellings that predate them by as much as several thousand years. Crofts are in a sense the territory for a lineage. The croft also serves as an aggregate social identity and has traditionally been the core of fishing crews. An individual's identity is often permanently linked with the croft even if he or she lives in other parts of the archipelago. Most topographical features of crofts have personal names associated with their previous inhabitants. Thus, crofts have become "historical repositories" of family lineages and the islands' cultural history (Cohen, 1987).

\footnotetext{
${ }^{16}$ All of the principal actors responding to the disaster in an official capacity were originally from the U.K. including Dr. Cox, the Director of Public Health; Malcolm Green, Executive Director of the Shetland Island Council; Martin Hall, Director of the Environmental Office. According to Wills (1991), most of the jobs at the Sullom Voe facility went to Scottish, Irish, and English workers - which contributes to the resentment of off-islanders.

${ }^{17}$ Parman $(1990$, p. 28$)$ provides us with an interesting account of the word croft: "The word croft is neither Gaelic nor a Scottish term. It comes from Old English and corresponds to the Dutch kroft, a field on high grounds or downs. Gaelic uses a number of words to refer to units of land ... but the word croft has entered Gaelic vocabulary fairly recently as a foreign, slightly Gaelized croit or lot (from allotment), the word for crofter as croitear. A croft is a small unit of agriculturally substandard land, as contrasted with farm, which is larger and more agriculturally viable."
} 
Seen from this perspective, the spraying of the crofts and their moors and the contamination of these croft dwellings, lands and topographical features was viewed by many as a violation perpetrated by an off-island, industrialized society. The crofters' inalienable right to the land was violated by the spraying of their lands and the refusal of U.K. officials to inform the crofters of the contents of the chemical solution that befouled both their economic livelihood and their crofters' cottages. Thus, the contamination and condemnation of the crofters' animals and lands threatened this way of life and desecrated, in a demonstrative way, the cultural heritage of the islands.

The above discussion illustrates that when public authorities are assessing risks they need not only to consider the physical and psychological risks that accompany an oil spill or the use of dispersants, but the risks to the social and cultural fabric of a community. It is imperative to recognize that the trauma inflicted by disasters has an impact on our socioecological system as a whole.

\section{DISCUSSION}

Illustrative of the way many technological disasters are handled, the response to the wreck of the Braer was to use a quick technological fix (Button, 1994b). The solution to the problem was seen as an issue of engineering and thus the human dimensions of the disaster were relegated to the background and all but ignored. The human component was eventually brought to the fore when the local people protested the indiscriminate use of dispersants and the disregard for their health and safety.

Why did Dr. Cox, the Director of Public Health, risk the credibility of his office so early in the disaster and refuse to release information that would enable the victims of the disaster to make their own risk analysis? The answer lies in at least two realms. In order to come to some "rational" judgment about the efficacy of using dispersants, Dr. Cox felt that he needed to know the chemical composition of the sprays. However, the manufacturers of the dispersants would not release the information unless it was under the cloak of "commercial confidence." In talking with Dr. Cox it was clear that he personally viewed his retaining of this confidence as a matter of great professional integrity. Constrained as he was by his own code of honor, he was also restricted by laws and policies of the United Kingdom which, despite being one of the seats of "democratic" tradition, has no right-to-know policy as formulated in the United States. 
The European Community has established procedures for the communication of hazardous information which are distinctly different from the approach in the United States, which is predicated on a federally mandated right-to-know law. ${ }^{18}$ The European community has an information policy named after the tragic chemical accident in Italy. The Seveso Directive (1979) has established a framework which delineates the responsibility of both industry and government to communicate hazardous information to the public. ${ }^{19}$ Industry is required to provide detailed accounts of toxic materials to a public authority; however, unlike the policy of the United States Government, the EC government authorities are not required to release the details of this information to the public (Collins, 1992). While information is seen as an important resource in both the United States and European community countries, European legislation and policies interprets public access to hazardous information based on a policy of the need to know rather than the right to know (Eijndhoven, 1994). Instead of having a policy of an openended access to all information, the Seveso Directive provides only access for specific information that is needed for a specific purpose. Within the European Community countries have varying policies as to the amount of access their citizens can have to risk data. The United Kingdom might be said to have the most restrictive approach in withholding information from the general public. U.K. policies place emphasis on providing scientific advisors with risk data and allowing them to make recommendations in the interest of the public, just as they did in the case of the Shetland Islands spill.

Beyond these policy restrictions it is probably safe to surmise, given many off-the-record comments to me by both Shetland and U.K. officials, that Dr. Cox, as an employee of the Scottish Home Office, was under considerable pressure from U.K. officials to minimize public concern and to protect corporate interests.

By March of 1993, Dr. Cox (Report dated Wednesday 31) adopted a different posture. In a conference report he stated:

\footnotetext{
${ }^{18}$ The United States Congress in 1980 passed the Comprehensive Environmental Response, Compensation and Liability Act, otherwise known as Superfund. The legislation was passed to identify toxic sites and polluters and to provide funding for clean-up. Later in 1986 Congress passed the Superfund Reauthorization Act (SARA) which included right-to-know provisions. Many states have also passed community right-to-know legislation which also is supposed to insure that information on hazardous materials be made available to the public. For an excellent discussion of the limitations of this act and its implementation, see Hadden (1994).

${ }^{19}$ Council Directive 82/501/EEC passed June 24, 1982. For a fuller discussion of this legislation, see Eijndhoven (1994).
} 
In this incident, the manufacturers of the chemical dispersants used would release the complete chemical composition of their dispersants to public health authorities only on the understanding that it would be held in commercial confidence. I can not think that such confidence was necessary. The chemicals used were not themselves secret in any way, and it is difficult to believe that commercial rivals are not themselves capable of analyzing their competitor's products. If it had been possible to make the composition of these products public it would have been relatively easy to reassure the public about the safety of their use, but because authorities dealing with the incident were unable to release this information not only was there an unjustifiable public concern about the use of these dispersants, but the secrecy surrounding their use and composition seriously undermined the confidence of the public in the pronouncements made about the relative lack of risk to the public from the incident as a whole. The withholding of this information was the most serious hindrance to handling the public health dimensions of this incident, and did no credit to the companies concerned.

Contrary to Dr. Cox's assertion, there still would have been controversy even if the information had been released to the public since the decision to use dispersants was quite controversial and undoubtedly unwise and unnecessary. Furthermore, the lack of adequate monitoring of both the environment and humans was unthinkable given the unique conditions surrounding the spill. There is no doubt, however, that the air of controversy would have been greatly diminished if vital information was not withheld from public scrutiny. The public had a right to ascertain for themselves the risks involved in the entire affair, their access to this information was critical; the refusal to release the information seriously eroded the credibility of the public health office to the point that the disaster victims became mistrustful of and hostile toward the office and increasingly suspicious of the circumstances surrounding the spill. The public clearly perceived that the interests of corporations were, in this instance, placed above the interests of the public.

As was noted in the introduction, uncertainty and controversy are not unusual in the wake of a technological disaster or oil spills in general. Considerable uncertainty was generated after the Shetland Islands oil spill, just as it was after the Exxon-Valdez oil spill (Button, 1993) or the Santa Barbara spill (1969) (Molotch, 1970; Easton, 1972). As in these other spills the climate of withholding information generated increased uncertainty about the credibility and trustworthiness of officials, since uncertainty is often "equated with surreptitiousness and incompetence" (Marrett, 1981). Moreover, increased uncertainty only adds to the number of interpretations which can be made about a disaster. In this case, as in most, the knowledge that was withheld was not only a key to meaning, but in very real terms a key to power (Keesing, 1987). People construct their social realities by making interpretations and conferring meaning based on knowledge. Access to knowledge is crucial. People employ knowledge in order to cope; they use knowledge to not only interpret events but to act. The limited 
access of the Shetland Islanders to knowledge left them in a precarious position and decreased their ability to both cope and to act. Both the U.K. disaster response team and the Public Health Office failed to incorporate into their response the perceptions and reactions of the local people. By not providing community members with hazard information, they denied the victims the knowledge with which to interpret and respond to the event in a meaningful manner. By withholding information, officials both narrowed the terms of the debate about the interpretation of the disaster and narrowed the number of informed participants who could participate in the debate.

If there is a lesson to be learned it is this: the local perception of risk is mediated by the perception of how risk is being managed by officials. As important as the disaster event itself, is the way it is perceived and interpreted by the community. Anxiety is minimized if the risk is perceived as being adequately managed and remediated; however, if local residents become distrustful of local government, local concern over risk will increase (see Fitchen et al., 1987; Edelstein, 1988; Button, 1993). The risk management strategies of the U.K. and the local public health office failed to take this into consideration and thus not only added to the air of uncertainty and anxiety, but made a crucial difference in whose interpretations were heard and whose interpretations were excluded.

\section{REFERENCES}

Button, G. (1994a). The Apocalypse Postponed: The Media Response to the Shetland Island Oil Spill. Paper on file with the author.

Button, G. (1994b). The Exxon-Valdez Oil Spill: An Environmental or Human Disaster? Paper presented at the Annual Meeting of the American Public Health Association, Washington, D.C., November 1.

Button, G. (1993). Social Conflict and the Formation of Emergent Groups In A Technological Disaster: The Exxon Valdez Oil Spill and the Response of the Residents in the Area of Homer, Alaska. Unpublished Doctoral dissertation, Department of Anthropology, Brandeis University.

Comaroff, J., and Roberts, S. (1981). Rules and Processes. University of Chicago Press, Chicago.

Clarke, L. (1989). Acceptable Risk? Making Decisions in a Toxic Environment. University of California Press, Berkeley, California.

Cohen, A. P. (1987). Whalsay: Symbol, Segment and Boundary in A Shetland Island Community. University of Manchester Press, Manchester, England.

Collins, J. (1992). The potential for right-to-know legislation in Canada. Intemational Journal of Mass Emergencies and Disaster 10(2): 349-364.

Cox, D. (1993). The Braer Incident. Health Impacts1: Immediate Impact-Response. Paper delivered Wednesday, March 31 at the Shetland Islands Marine Environment Conference, Lerwick.

Cox, D., MD (1993). Interview with the author. Director of Public Health for the Shetland Islands, Lerwick, February 8. 
Easton, R. (1972). Black Tide: The Santa Barbara Oil Spill and Its Consequences. Delacorte Press, New York.

Edelman, M. (1977). Political Language. Academic Press, New York.

Edelstein, M. (1988). Contaminated Communities. Westview Press, Boulder, Colorado.

Eijndhoven, J. van (1994). Disaster prevention in Europe. In Jasanoff, S. (ed.), Learning from Disaster. University of Pennsylvania Press, Philadelphia.

Fitchen, J., Heath, J. S. and Fessenden-Raden, J. (1987). Risk perception in community context: A case study. In: Jasanoff, S. (ed.), The Social and Cultural Construction of Risk. D. Reidel Publishing Company, Dordrecht, pp. 31-54.

Fogg, R. (1993). Health study results "reassuring." The Shetland Times Lerwick, Friday, February 26, p. 9.

Freudenberg, W. (1988). Perceived risk: Real risk: Social science and the art of probabilistic risk assessment. Science 244: 127.

Green, M. (1993). Interview with the author. Executive Director of the Shetland Islands Council, Lerwick, February 9.

Gusfield, J. (1981). The Culture of Public Problems. The University of Chicago, Chicago.

Hadden, S. G. (1994). Citizen participation in environmental policy making. In Jasanoff, S. (ed.), Learning from Disaster. University of Pennsylvania Press, Philadelphia, pp. 91-112.

Hall, M. (1993). Interview with the author. Director of Environmental Services, The Shetland Islands Council, Lerwick, February 9.

Jasanoff, S. (1988). The Bhopal disaster and the right to know. Social Science and Medicine 27(10): 1113-1123.

Keesing, R. (1987). Anthropology as interpretive quest. Current Anthropology 28: 161-176.

Latin, L. (1988). Good science, bad regulation, and toxic risk assessment. Yale Journal on Regulation 5: 89-148.

Lave, L. (1986). Approaches to risk management: A critique. In Covello, V. T., Menkes, J., and Mumpower, J. (eds.), Risk Evaluation and Management. Plenum Publishing Corporation, New York.

Levine, A. (1982). Love Canal: Science, Politics, and People. Lexington Books, Lexington.

Marrett, C. (1981). The accident at three mile island and the problem of uncertainty. In Stills, D., and Moss, T. (eds.), The Three Mile Island Nuclear Accident: Lessons and Implications. Annal of the New York Academy of Sciences, Vol. 365, April 24, New York, pp. 280-291.

Merry, S. (1990). Getting Justice and Getting Even. The University of Chicago Press, Chicago.

Mileti, D., Drabeck, D., and Hass, J. (1975). Human Systems in Extreme Environments. University of Colorado Institute of Behavioral Science, Boulder, Co.

Molotch, H. (1970). Oil in Santa Barbara and power in America. Sociological Inquiny 4: 131-144.

National Research Council (1989). Using Oil Dispersants on the Sea. National Academy Press, Washington, D.C.

Ozonoff, D., and Boden, L. (1987). Truth and consequences: Health Agency responses to environmental health problems. Science, Technology, and Human Values 12(3\&4): 70-77.

Parman, S. (1990). Scottish Crofters. A Historical Ethnography of a Celtic Village. Holt, Rinehart and Winston, Fort Worth.

Rappaport, R. A. (1988). Toward postmodern risk analysis. Risk Analysis 8(2): 189-191.

Rappaport, R. (1993). The anthropology of trouble. American Anthropologist 95: 295-303.

Reich, M. (1991). Toxic Politics. Responding to Chemical Disasters. Cornell University Press, Ithaca.

Rosen, D. H., and Voorhees-Rosen, D. (1978). The Shetland Islands: The effects of social and ecological change on mental health. Culture, Medicine and Psychiatry 2: 41-68.

Rosen, L. (1984). Bargaining for reality. University of Chicago Press, Chicago.

Rowlands, C., MD (1993). Interview with the author. Dunross Parish General Practitioner, Levenwick, February, 15.

Shetland Islands Council (1993). Public Notice. Lerwick, January 10.

Shetland Islands Council (1993). Public Notice: Action to Take to Minimalize Skin Contact with Oil Deposits. Lerwick, January 16.

Shetland Islands Council (1993). Press Release. Lerwick, January 27. 
Shetland Islands Council (1993). Public Health Advice (concerning: "water supply"; "crops"; "exposure to airborne pollution"; and "personal respiratory protection." Lerwick, undated.

Shetland Islands Council (1993). The Use of Dispersents. Lerwick, undated.

Shetland Islands Council (1993). Public Health Advice. General statement issued to the public, Lerwick, January 29.

Shrader-Frechette, K. S. (1991). Risk and Rationality. University of California Press, Berkeley. Slovic, P. (1987). Perceptions of risk. Science 236: 280-285.

U.S. Congress, Office of Technology Assessment (1990). Coping with an Oiled Sea. Background Paper. U.S. Government Printing Office, Washington, D.C.

Wallace, A. P. (1987). St. Clair: A Nineteenth Century Coal Town's Experience with a Disaster-Prone Industry. Cornell University Press, Ithaca.

Wills, J. (1991). A Place in the Sun: Shetland and Oil-Myths and Realities. Mainstream Publishing, Edinburgh.

Wolf, E. (1990). Facing power: Old insights, new questions. American Anthropologist 92: 586-596.

Yergin, D. (1992). The Prize. The Epic Quest for Oil, Money, and Power. Simon \& Schuster, New York. 